\title{
Illuminating Vertebrate Olfactory Processing
}

\author{
Hartwig Spors, ${ }^{1}$ Dinu Florin Albeanu, ${ }^{2}$ Venkatesh N. Murthy, ${ }^{3}$ Dmitry Rinberg, ${ }^{4}$ Naoshige Uchida, ${ }^{3}$ Matt Wachowiak, ${ }^{5}$ \\ and Rainer W. Friedrich ${ }^{6}$ \\ ${ }^{1}$ Department of Molecular Neurogenetics, Max Planck Institute of Biophysics, 60438 Frankfurt am Main, Germany, ${ }^{2}$ Cold Spring Harbor Laboratory, Cold \\ Spring Harbor, New York 11724, ${ }^{3}$ Center for Brain Science, Department of Molecular and Cellular Biology, Harvard University, Cambridge, Massachusetts \\ 02138, ${ }^{4}$ Janelia Farm Research Campus, Howard Hughes Medical Institute, Ashburn, Virginia 20147, ${ }^{5}$ Department of Neurobiology and Anatomy, Brain \\ Institute, University of Utah, Salt Lake City, Utah 84132, and ' Friedrich Miescher Institute for Biomedical Research, 4058 Basel, Switzerland
}

The olfactory system encodes information about molecules by spatiotemporal patterns of activity across distributed populations of neurons and extracts information from these patterns to control specific behaviors. Recent studies used in vivo recordings, optogenetics, and other methods to analyze the mechanisms by which odor information is encoded and processed in the olfactory system, the functional connectivity within and between olfactory brain areas, and the impact of spatiotemporal patterning of neuronal activity on higher-order neurons and behavioral outputs. The results give rise to a faceted picture of olfactory processing and provide insights into fundamental mechanisms underlying neuronal computations. This review focuses on some of this work presented in a Mini-Symposium at the Annual Meeting of the Society for Neuroscience in 2012.

\section{Introduction}

Olfactory systems have evolved to perform sophisticated, survival-relevant analyses of the molecular environment. Odor information is sampled by a large number of odorant receptors, transformed into electrical activity by olfactory sensory neurons (OSNs), and presented to the brain as combinatorial patterns of activity across discrete input channels, the olfactory glomeruli. In vertebrates, these input patterns are processed in the olfactory bulb $(\mathrm{OB})$ by neuronal circuits consisting of principal neurons, the mitral/tufted (MT) cells, and a variety of local interneurons. Output of the $\mathrm{OB}$ is conveyed to multiple cortical and subcortical target areas including piriform cortex, anterior olfactory nucleus, olfactory tubercle, cortical amygdala, and entorhinal cortex. Many of these brain areas are interconnected and project back to the $\mathrm{OB}$. Consistent with these centrifugal projections, the activity of neurons in the $\mathrm{OB}$ and higher brain areas is not only modulated by odors but also by behavioral variables and contextdependent cues (Kay and Laurent, 1999; Doucette and Restrepo, 2008).

The array of glomeruli exhibits a coarse chemotopic organization that is, however, not as distinct as topographic maps in other sensory systems and does not predict the arrangement of glomeruli at fine spatial scales (Friedrich and Korsching, 1997;

\footnotetext{
Received July 10, 2012; revised Aug. 27, 2012; accepted Aug. 28, 2012.

Work in the authors' laboratories is funded by the Max Planck Society, Novartis Research Foundation, Swiss Nationalfonds, Human Frontiers Science Program, Deutsche Forschungsgemeinschaft (Grant SPP 1392), the European Union, Howard Hughes Medical Institute, National Institute on Deafness and Other Communication Disorders, Cold Spring Harbor Laboratory Startup, Whitehall Foundation, and the German Israeli Foundation.

Correspondence should be addressed to either of the following: Rainer W. Friedrich, Friedrich Miescher Institute for Biomedical Research, 4058 Basel, Switzerland, E-mail: Rainer.Friedrich@fmi.ch; or Hartwig Spors, Max Planck Institute of Biophysics, 60438 Frankfurt am Main, Germany, E-mail: haspors@biophys.mpg.de.

D. Rinberg's present address: New York University Neuroscience Institute and Department of Physiology \& Neuroscience, New York University Langone Medical Center, New York, NY 10016.

DOI:10.1523/JNEUROSCI.3328-12.2012

Copyright $\odot 2012$ the authors $\quad 0270-6474 / 12 / 3214102-07 \$ 15.00 / 0$
}

Uchida et al., 2000; Mori et al., 2006; Soucy et al., 2009), raising the question whether interactions between neurons associated with different glomeruli are organized by topography (Yokoi et al., 1995) or by other principles. At least some interglomerular interactions are sparse and extend over long distances (Fantana et al., 2008; Kim et al., 2011, 2012), but the underlying rules, if any, remain obscure. In piriform cortex, no obvious topography was detected in afferent projections, intracortical connectivity, and odor-evoked activity patterns (Johnson et al., 2000; Stettler and Axel, 2009; Yaksi et al., 2009; Franks et al., 2011; Ghosh et al., 2011; Miyamichi et al., 2011; Sosulski et al., 2011). The principles governing functional connectivity within and between olfactory brain areas are therefore an important subject of research in olfaction.

Patterns of odor-evoked activity exhibit temporal structure that may arise from at least three sources. First, temporal structure may be imposed upon a stimulus by odor-sampling mechanisms such as sniffing in mammals or antennal flicking in arthropods (Wachowiak, 2011). Second, slow modulations of firing rates and fast oscillatory synchronization can be generated by synaptic interactions in the OB and elsewhere (Laurent, 2002). Third, the concentration of an odor can fluctuate in time due to movements of the carrier medium (air or water). Such fluctuations may convey important information about an odor source, as demonstrated for insects (Murlis et al., 1992). This raises the question how spatiotemporal odor representations are organized and decoded, and how features of such representations may be reflected in olfactory behaviors.

These and other questions were addressed in recent studies using a wide range of techniques including optogenetics (Yizhar et al., 2011). Using light rather than odors to stimulate neurons in the olfactory system allowed, for example, for systematic and precise manipulation of activity patterns in space and time, even in awake, behaving animals. The results have challenged prevailing hypotheses such as the notion that precise timing of sensory 


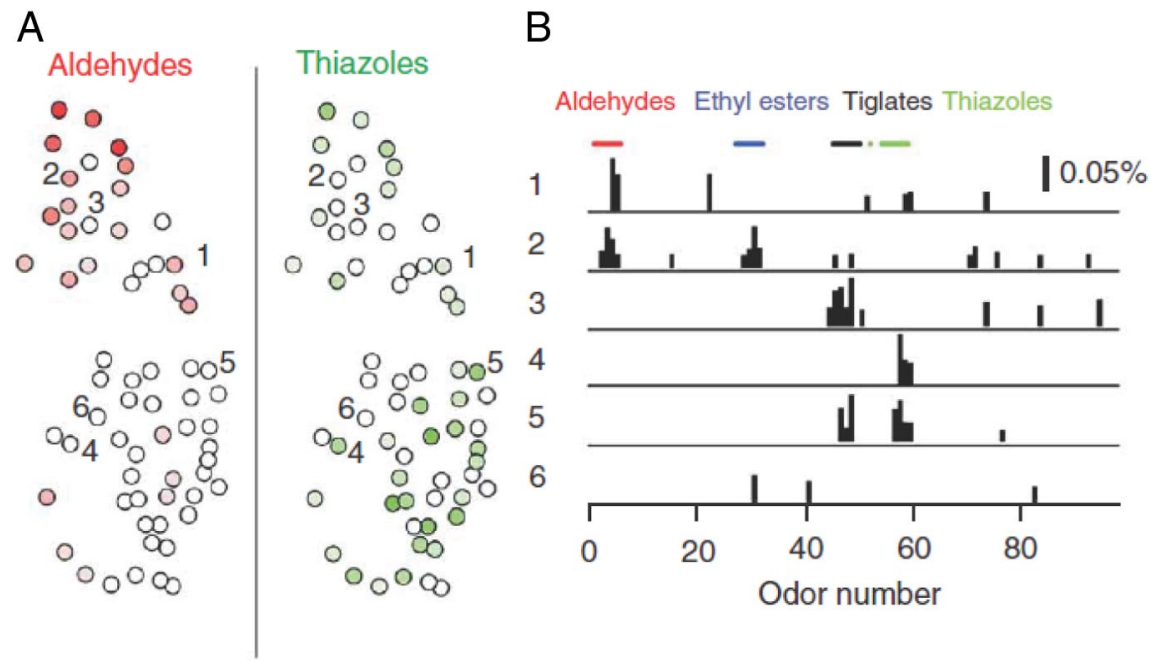

Figure 1. Distributed glomerular responses in the $O B . A$, Glomeruli responding to odorants with different functional groups (aldehydes, thiazoles) are distributed and interspersed on the dorsal surface of the $0 \mathrm{~B}$. $\boldsymbol{B}$, Odor response spectra of glomeruli labeled in $\boldsymbol{A}$ showing that individual glomeruli can respond to multiple classes of odorants, and that neighboring glomeruli often have non-overlapping response profiles (modified from Soucy et al., 2009).

responses is not exploited for olfactory coding. Together, recent results provided new insights into fundamental mechanisms of neuronal processing and substantially refined the current picture of olfactory processing in vertebrates. The focus of this review is on some of this work presented in a Mini-Symposium at the 42nd Annual Meeting of the Society for Neuroscience. Other recent findings, including results from invertebrates, can, unfortunately, not be reviewed in depth.

\section{Odor representations by activity patterns across glomeruli}

In the main olfactory system, axons of OSNs expressing the same odorant receptor converge onto a few defined glomeruli within the OB (Buck, 2000). Because an odorant activates multiple odorant receptors, odor information is encoded combinatorially by dynamic patterns of multiple responsive glomeruli (Leveteau and MacLeod, 1966; Friedrich and Korsching, 1997; Spors and Grinvald, 2002; Spors et al., 2006; Koulakov et al., 2007). Positions of individual glomeruli are conserved between individuals with a precision of one or a few glomerular diameters (Strotmann et al., 2000; Soucy et al., 2009). This stereotyped and precise layout of the glomerular array does not, however, imply a "chemotopic" spatial organization similar to topographic maps in other sensory systems. Rather, chemotopy is defined functionally, referring to a systematic mapping of features in molecular stimulus space onto spatial coordinates in the brain. In a chemotopic map, it may thus be expected that responses to odorants with different functional groups are mapped to distinct spatial domains of the $\mathrm{OB}$, and that glomeruli responding to similar odorants are located in close proximity to each other.

In rodents, a chemotopic organization of the glomerular array was proposed based on the finding that odors with different functional groups and carbon chain length activated glomeruli or MT cells within different domains of the OB (Johnson and Leon, 2000; Uchida et al., 2000; Meister and Bonhoeffer, 2001; Mori et al., 2006). However, other widefield imaging studies, some of which used $>100$ odorants, have produced a more complex picture (Friedrich and Korsching, 1997; Bozza et al., 2004; Soucy et al., 2009; Murthy, 2011; Ma et al., 2012). Although spatial biases of glomerular responses to particular functional groups were observed at a lished observations).

coarse scale ( $\sim 1 \mathrm{~mm}$ in rodents), apparent functional domains were fractured and spatially overlapping (Fig. 1A). Moreover, no obvious chemotopic organization was observed at finer spatial scales; rather, responses of neighboring glomeruli were as diverse as those of more distant ones (Soucy et al., 2009; but see also Ma et al., 2012) (Fig. 1B). An estimate for the spatial scale of polysynaptic interactions among MT cells associated with different glomeruli may, in first approximation, be derived from the length of their basal dendrites and by the distance of short axon cell projections. Both these lengths are in the range of $1 \mathrm{~mm}$ or less (Shepherd et al., 2004). Responses of MT cells may thus be influenced by functionally heterogeneous glomeruli scattered throughout a large region (Fantana et al., 2008), essentially unconstrained by chemotopic rules (D. F. Albeanu and V. Murthy, unpub-

\section{Spatiotemporal activity patterns in the $\mathrm{OB}$}

In the $\mathrm{OB}$, glomerular activity patterns are processed by a network of MT cells and various classes of local interneurons including GABAergic periglomerular cells in superficial layers, GABAergic granule cells in deeper layers, glutamatergic external tufted cells, short-axon cells releasing both GABA and dopamine, and others (Wachowiak and Shipley, 2006) (Fig. 2A). This network has been proposed to perform various tasks including a normalization of response intensity, a decorrelation of overlapping activity patterns, and feature extraction (Yokoi et al., 1995; Friedrich and Laurent, 2001; Arevian et al., 2008; Niessing and Friedrich, 2010; Olsen et al., 2010; Padmanabhan and Urban, 2010; Wiechert et al., 2010; Koulakov and Rinberg, 2011; Cleland and Linster, 2012).

A variety of approaches has recently contributed to a more advanced understanding of olfactory processing in the $\mathrm{OB}$ and higher brain areas. Transgenic and viral methods have been used to target fluorescent proteins, genetically encoded calcium indicators, and optogenetic probes to defined glomeruli and neuron types. Together with advanced imaging technology, these approaches allow for electrophysiological and optical recordings from identified neurons and glomeruli in vitro and in vivo. Moreover, the combination of optogenetic stimulation and electrophysiology permits the identification of neuron types in extracellular recordings (Lima et al., 2009; Dhawale et al., 2010; Cohen et al., 2012). Importantly, optogenetic activation of OSNs or MT cells enables precise spatial and temporal control over the evoked activity patterns. This is desired for systematic approaches in sensory physiology but has been a notorious problem in olfaction. Moreover, recent in vivo studies in rodents achieved detailed analyses of spatial and temporal activity patterns in awake animals rather than under anesthesia (Cury and Uchida, 2010; Shusterman et al., 2011; Smear et al., 2011; Gschwend et al., 2012; Miura et al., 2012). This is an important step because activity patterns in the $\mathrm{OB}$ can differ significantly under these conditions (Adrian, 1950; Rinberg et al., 2006).

Many concepts of olfactory processing in vertebrates are based largely on olfactory coding by spatial patterns or neuronal iden- 
tity (Yokoi et al., 1995; Cleland and Linster, 2012). However, odor-evoked activity patterns in the $\mathrm{OB}$ are also highly dynamic, sometimes evolving over hundreds of milliseconds or even seconds (Laurent, 2002). Moreover, odors can evoke oscillatory population activity in the theta, beta, and gamma frequency ranges that reflects the rhythmic synchronization of stimulus-specific neuronal ensembles. Pioneering work in insects, but also in vertebrates, indicates that this dynamics may convey additional stimulus information and may play important roles in the processing of odor representations (Laurent, 2002). Recent studies have now examined temporal patterning of activity in the rodent $\mathrm{OB}$ in detail.

Optical imaging using voltage- and calcium-sensitive dyes revealed odor-specific latencies and dynamics of glomerular responses (Spors and Grinvald, 2002; Spors et al., 2006) (Fig. 2B) and extracellular recordings uncovered rich temporal patterning of MT cell responses (Cury and Uchida, 2010; Dhawale et al., 2010; Shusterman et al., 2011). Importantly, olfactory processing in rodents is temporally constrained by sniffing, which changes in frequency from $2-3 \mathrm{~Hz}$ during slow breathing to $7-10 \mathrm{~Hz}$ during active exploration (Fig. 2C). Information processing is thus likely to occur within successive 100-200 ms epochs of transient activity (Cury and Uchida, 2010; Shusterman et al., 2011).

The prominence of respiration-driven dynamics at all levels of the mammalian olfactory CNS suggests that olfactory processing networks actively shape the temporal structure of odor-evoked activity. Indeed, external tufted cells can be entrained to phasic inputs in vitro, which enhance their drive onto MT cell activity at frequencies corresponding to natural sniffing (Hayar et al., 2004; Wachowiak and Shipley, 2006). Likewise, inhalationlocked temporal patterning of MT cell activity in vivo actually becomes sharper at higher sniff frequencies, even though it becomes weaker in sensory inputs (Carey and Wachowiak, 2011; Shusterman et al., 2011). Even in awake mice, where spontaneous activity is high, odor responses of MT cells are phase locked to the sniff cycle with a precision of $\sim 10 \mathrm{~ms}$, as revealed by temporally precise odor stimulation in head-fixed animals (Shusterman et al., 2011).

In awake mice performing odorguided tasks, odor-evoked activity patterns across MT cells exhibit complex, phase-locked temporal dynamics within
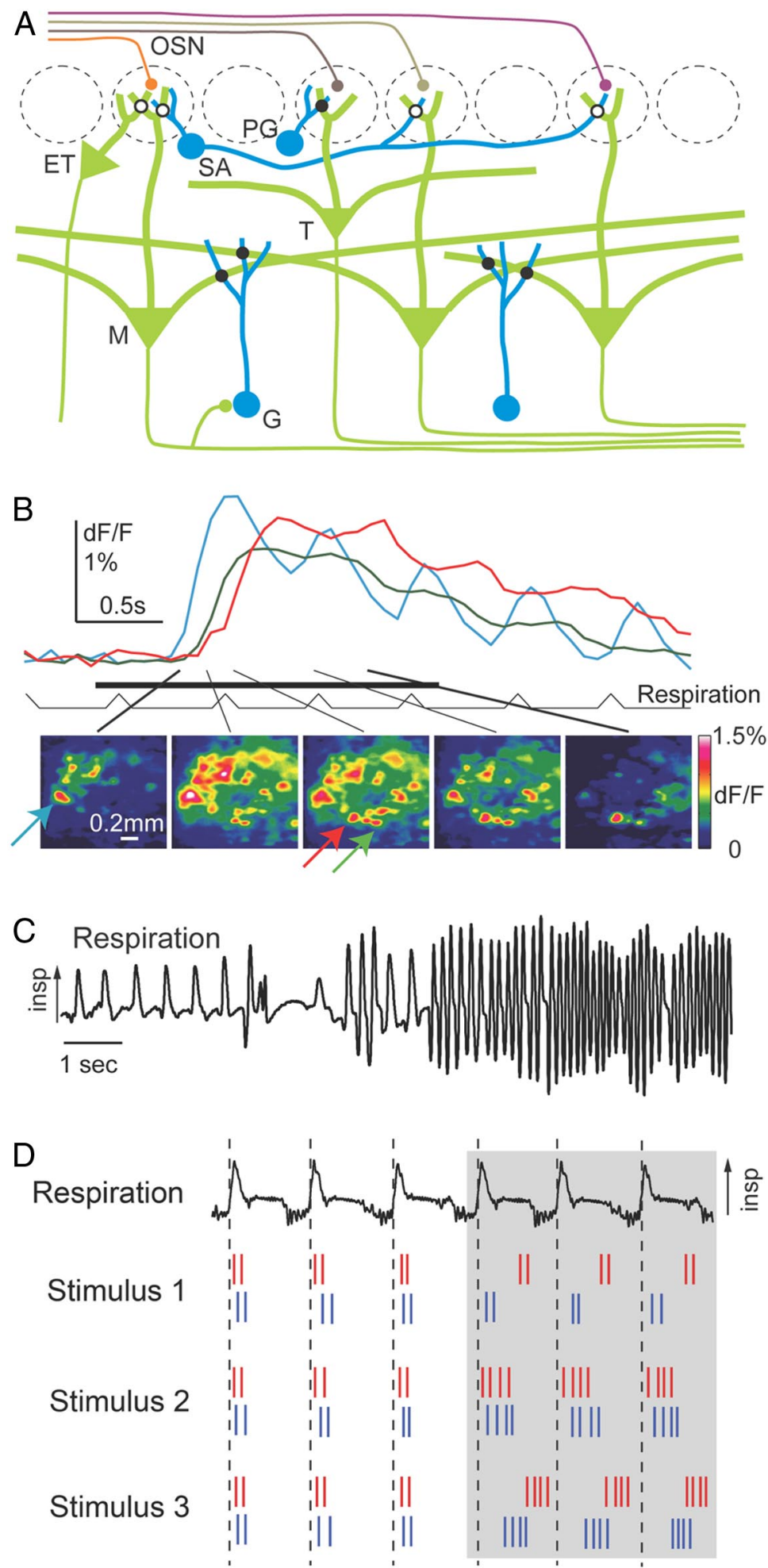

Figure 2. $\quad \boldsymbol{A}$, Schematic architecture of the olfactory bulb. Filled circles on the intersection of processes denote bidirectional synaptic connections; filled circles that abut neurons indicate polarized axo-dendritic synapses. Open circles indicate connections that are suspected but not directly confirmed or are mediated by diffuse extrasynaptic signaling. ET, External tufted; $G$, granule; $M$, mitral; $P G$, periglomerular; $S A$, short-axon; T, tufted. $\boldsymbol{B}$, Top, Response time course of three glomeruli (see arrows with corresponding colors below) to ethyl butyrate (1\% saturated vapor). Bottom, Patterns of fluorescence signals in 154 ms time windows centered on the time points indicated by lines (modified from Spors et al., 2006). C, Respiration (measured as intranasal pressure) in an awake, freely moving rat, showing changes in frequency, amplitude and duration of individual "sniffs" — as well as pauses in breathing - within a 15 s span. Arrow indicates direction of inspiration (modified from Wachowiak, 2011). D, Spike trains from two sister MT cells (red and blue) and respiration (top). Sister cell responses to different odors have similar firing rates, but can have different phases (modified from Dhawale et al., 2010). 
the timeframe of a sniff cycle (Chaput, 1986; Cury and Uchida, 2010; Shusterman et al., 2011; for anesthetized animals, see Dhawale et al., 2010; Carey and Wachowiak, 2011) (Fig. 2D). These temporal ensemble patterns contained substantial odor information, particularly during the first $\sim 100 \mathrm{~ms}$ after inhalation onset. More pronounced firing rate modulations during short time windows within a sniff $(\sim 30 \mathrm{~ms})$, but not firing rates averaged over the entire sniff $(\sim 160 \mathrm{~ms})$, were correlated with shorter behavioral reaction times on a trial-by-trial basis, consistent with the hypothesis that the dynamics of odor responses is used for odor identification (Cury and Uchida, 2010).

When sniffing frequency was decreased by changing the task design, the duration of inhalation and the activity patterns during this phase were largely preserved, indicating that the dynamics of MT activity during the initial phase of the sniff cycle is remarkably stable (Cury and Uchida, 2010). In another study using head-fixed animals, trial-to-trial variations in sniff duration were associated with temporal stretching or compression of the MT cell activity pattern. As a consequence, the phase of MT cell responses relative to the sniff cycle was invariant to variability in sniff duration (Shusterman et al., 2011). This temporal scaling may be explained by the assumption that faster inhalation produces a steeper rise in odor concentration in the nose and, thus, faster responses of the bulbar network. The somewhat different observations of these studies may now be further explored.

To examine whether mice are able to detect subtle differences in the timing of sensory input, OSNs expressing channelrhodop$\sin 2(\mathrm{Chr} 2)$ were stimulated by light in mice implanted with an optical fiber in the nasal cavity (Smear et al., 2011). This approach made it possible to vary the timing of the stimulus relative to the sniffing cycle without changing the spatial pattern of stimulation. Mice could be trained to discriminate with $>90 \%$ accuracy between two brief $(1 \mathrm{~ms})$ light pulses presented during inhalation and $100 \mathrm{~ms}$ later. Even when the temporal differences between two stimuli were as small as $10 \mathrm{~ms}$, mice were able to perform the task above chance level (Fig. 3). Hence, mice can solve an olfactory discrimination task purely based on temporal cues in the stimulus. MT cells, however, responded to optical stimulation at different times with different firing rates, indicating that temporal information in the stimulus is transformed into different spatial patterns of neuronal activity in the brain, which may be the basis for behavioral decisions (Smear et al., 2011). The striking temporal acuity of the system and the ease with which mice learn to discriminate between temporal cues suggests that information contained in the timing of responses is also used during natural odor stimulation.

Output from each glomerulus is transmitted to higher brain areas by multiple (20-50) MT cells (sister cells). Since these cells receive common sensory input, the question arises whether they carry redundant information to downstream circuits (Chen et al., 2009; Kazama and Wilson, 2009; Padmanabhan and Urban, 2010), or whether they are functionally diverse. To address this question, a digital micromirror device was used to optically stimulate individual glomeruli in mice expressing $\mathrm{Chr} 2$ in OSNs, and sister cells connected to the stimulated glomerulus were identified by their time-locked spike responses. Subsequent odor stimulation showed that sister cells responded to odorants with similar firing rate changes but differed in their spike timing (Dhawale et al., 2010). At rest, sister cells spiked in a synchronized manner. During odor presentation, however, temporal firing patterns of sister cells became decorrelated in a stimulus-specific manner, to the same degree as among non-sister cells. While the common excitatory sensory input can readily explain the similar

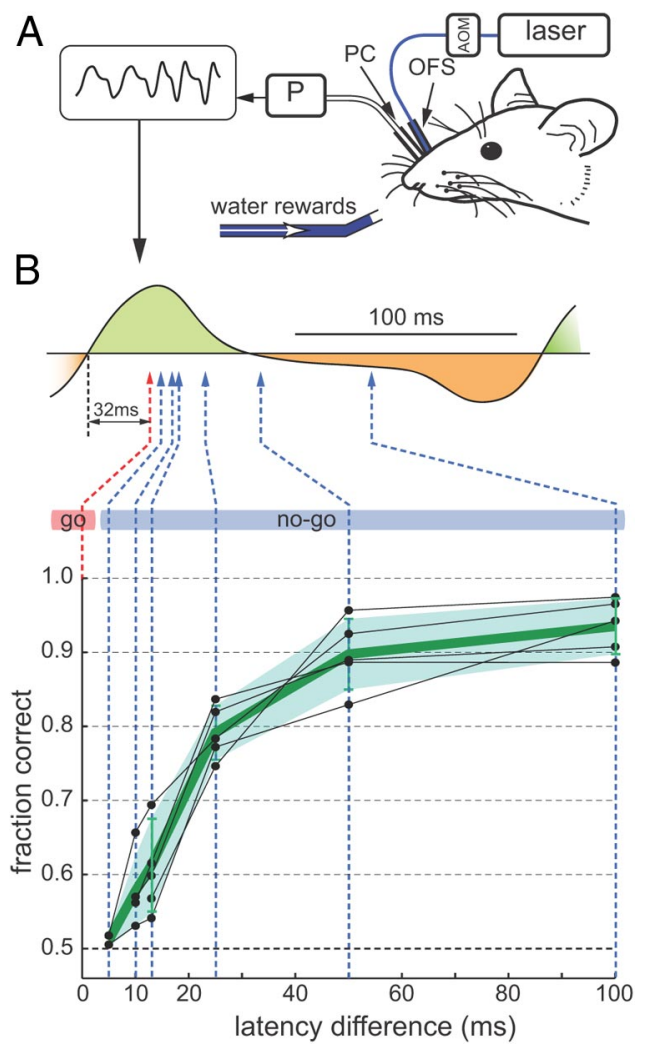

Figure 3. Perception of stimulus time differences relatively to the sniffing cycle. $A$, Mice were implanted with a nasal optical fiber stub (OFS) to deliver light, gated by an acousto-optic modulator (AOM). A nasal pressure cannula ( $\mathrm{PC}$ ) coupled to a pressure sensor $(\mathrm{P})$ measured sniffing. Inverted intranasal pressure signal is shown at top left. $\boldsymbol{B}$, Top, Schematic of the sniff time discrimination problem, shown relative to a typical sniffwaveform, with inhalation shaded green and exhalation shaded orange. Light was delivered $32 \mathrm{~ms}$ after inhalation onset (red arrow) in "go" trials and sometimes later (blue arrow) in "no-go" trials. Bottom, Performance of individual OMP-Chr2 mice $(n=5)$ (black dots). Green line and shaded region show average performance and SD (modified from Smear et al., 2011).

changes in average firing of sister cells, mechanisms underlying temporal decorrelation remain elusive. One possibility is that sister cells receive distinct lateral inhibitory inputs from juxtaglomerular or granule cells. Together, these recent results argue for the coexistence of information in the rate and in the timing of action potential output from MT cells (Cury and Uchida, 2010; Dhawale et al., 2010; Shusterman et al., 2011). Moreover, the number of functionally distinct output channels of the $\mathrm{OB}$ is higher than the number of input channels (glomeruli).

Transformations of spatiotemporal activity patterns in the $\mathrm{OB}$ and the underlying mechanisms are now further analyzed by optogenetic approaches. For example, in vitro studies predict that GABAergic (GAD65+) periglomerular interneurons play a role in shaping both the overall excitability and the temporal response pattern of MT cells (Gire and Schoppa, 2009; Shao et al., 2012). This hypothesis is now being tested by expressing the inhibitory opsin Arch in these neurons. Similar approaches are also used to test the functions of other interneurons in the $\mathrm{OB}$ of mice and zebrafish. Moreover, recent studies indicate that biophysical variation among neurons of the same type can contribute to the computational function of the OB network (Padmanabhan and Urban, 2010; Angelo et al., 2012).

\section{Transformations of odor representations in olfactory cortex} The largest target area of the $\mathrm{OB}$ is the piriform cortex, a threelayered paleocortical brain area that has been proposed to estab- 

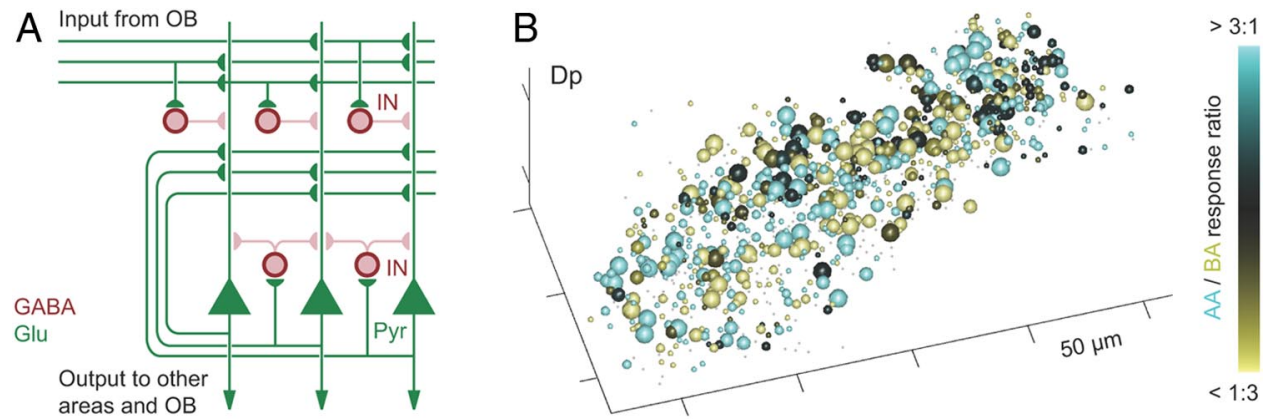

Figure 4. Responses in higher olfactory areas. $A$, Simplified scheme of piriform cortex. $B$, Distributed, overlapping activity patterns evoked by two dissimilar odors (AA, amino acid; BA, bile acid) in Dp of adult zebrafish, measured by two-photon calcium imaging. Plot symbols indicate neurons, size of spheres indicates response magnitude to stronger stimulus, color code indicates response ratio (modified from Yaksi et al., 2009). IN, Interneuron; Pyr, pyramidal neuron.

lish synthetic representations of olfactory objects and to function as an auto-associative memory network (Haberly, 2001; Wilson and Sullivan, 2011; Chapuis and Wilson, 2012). Pyramidal neurons in piriform cortex receive nontopographic excitatory input from diverse sets of MT cells (Nagayama et al., 2010; Ghosh et al., 2011; Miyamichi et al., 2011; Sosulski et al., 2011; Igarashi et al., 2012) and form sparse connections with other pyramidal neurons independent of distance (Johnson et al., 2000; Franks et al., 2011). Moreover, pyramidal neurons receive powerful inhibitory input from different classes of local GABAergic interneurons (Poo and Isaacson, 2009; Stokes and Isaacson, 2010; Suzuki and Bekkers, 2010) (Fig. 4A). Consistent with the distributed character of afferent and intrinsic connections, large-scale multiphoton calcium imaging showed that odors evoke scattered, moderately sparse patterns of activity in piriform cortex and in the homologous brain area in zebrafish, the posterior zone of the dorsal telencephalon (Dp) (Stettler and Axel, 2009; Yaksi et al., 2009) (Fig. $4 B$ ). These studies also demonstrated that activity patterns evoked by binary mixtures deviated substantially from responses to the individual components. Optical stimulation of glomeruli using $\mathrm{Chr} 2$ or glutamate uncaging showed that piriform neurons integrate spatially distributed inputs from the $\mathrm{OB}$, often exhibiting superlinear responses to multiple inputs (Arenkiel et al., 2007; Davison and Ehlers, 2011). These results are consistent with the notion that odor representations are synthetic in nature (Haberly, 2001; Wilson and Sullivan, 2011).

Extracellular recordings in rats performing an odor discrimination task showed that neurons in piriform cortex responded to odor stimulation with simple, burst-like activities time locked to inhalation onset (Miura et al., 2012). Spike counts of these bursts conveyed more reliable and rapid information than temporal patterns, suggesting that the significance of temporal patterns is greatly reduced in the anterior piriform cortex compared with the olfactory bulb. Cortical circuits may therefore detect timing differences between MT cells and transform them into a firing rate response. In theory, this could be accomplished by various mechanisms including delay lines, feedforward inhibition, or recurrent inhibition (Perez-Orive et al., 2002; Luna and Schoppa, 2008; Stokes and Isaacson, 2010). These issues can now be further explored by temporally precise optical stimulation of MT cells in the OB.

The impact of temporally patterned MT cell activity on higher-order neurons was examined in area Dp of adult zebrafish, the homolog of piriform cortex in other vertebrates. Since zebrafish inhabit slow or still waters and do not sniff, natural stimuli are unlikely to exhibit pronounced temporal structure. However, temporal patterning of MT cell activity results from interactions among neurons in the OB. Odor stimuli with a rise time of $\sim 600$ ms produced MT cell activity patterns that were dynamically reorganized before they approached a steady state after a few hundred milliseconds (Friedrich and Laurent, 2001; Niessing and Friedrich, 2010). Concomitantly, subsets of MT cells rhythmically synchronized their action potentials at a frequency near $20 \mathrm{~Hz}$. Activity patterns across synchronized MT cells conveyed information about the molecular category of an odorant, but information about its precise identity was represented mostly by ensembles of nonsynchronized MT cells during the steady state (Friedrich et al., 2004). The information that is retrieved from MT activity patterns therefore depends on the impact of synchronization on higher-order neurons, and on the time window during the response.

To examine how activity patterns are temporally filtered in $\mathrm{Dp}$, axon terminals of OSNs expressing $\mathrm{Chr} 2$ in the OB were optically stimulated using a digital micromirror array. Using this approach, it was possible to vary oscillatory synchrony among distributed ensembles of MT cells without major changes in firing rates (Blumhagen et al., 2011; Zhu et al., 2012). Surprisingly, firing rates of Dp neurons did not increase with synchrony in their inputs, and odor stimulation evoked only small oscillatory membrane potential fluctuations. Although these fluctuations influenced action potential timing, firing rates of $\mathrm{Dp}$ neurons depended primarily on the magnitude of a large and slow depolarization, which in turn depended on the balance between excitatory and inhibitory synaptic input (Yaksi et al., 2009; Blumhagen et al., 2011). Neuronal circuits in Dp therefore attenuate the impact of synchrony, at least in part because passive neuronal properties act as strong low-pass filters. Moreover, most responses occurred during the decorrelated steady state of MT cell input (Blumhagen et al., 2011). Temporal filtering therefore tunes $\mathrm{Dp}$ neurons to those features of input patterns that are particularly informative about precise odor identity.

The olfactory brain, like other sensory areas, does not simply integrate sensory information in a passive manner to create a complete and accurate representation of the sensory scene. Instead, sensory responses are modulated by the behavioral state and prior experience even at the earliest processing stages. Such top-down modulation is thought to involve projections from central back to more peripheral brain areas (Knudsen, 2007; Restrepo et al., 2009), which are prominent in the olfactory system. The $\mathrm{OB}$ itself receives dense projections from olfactory cortex as well as neuromodulatory inputs from other areas. Moreover, different cortical regions are interconnected with each other (Shepherd et al., 2004; Matsutani and Yamamoto, 2008). Recent in vitro studies have begun to uncover the synaptic properties of centrif- 
ugal axons projecting back to the $\mathrm{OB}$ (Gao and Strowbridge, 2009), but the cellular targets of feedback projections, their functional properties, and their effects on olfactory processing in vivo remain largely unknown.

Optogenetic methods have a particular advantage over other techniques when examining connectivity across different areas because long-distance projection axons can be selectively activated near the target regions (Petreanu et al., 2007). This capability has recently been exploited in rodents to study functional connectivity patterns among the anterior olfactory nucleus, the anterior piriform cortex, and posterior piriform cortex (Hagiwara et al., 2012). Moreover, optogenetic stimulation of pyramidal neurons demonstrated that excitatory connectivity within piriform cortex is extremely widespread and sparse, whereas inhibitory connections are more local (Franks et al., 2011).

Optogenetic manipulations are also used to examine the functional role of feedback connections from cortical areas to the OB. Initial studies have focused on the dense bilateral projections from the anterior olfactory nucleus to the $\mathrm{OB}$ (F. Markopoulos, D. Rokni, D. Gire, and V. Murthy, unpublished data). By expressing Chr2 in the anterior olfactory nucleus and optical stimulation of the projecting axons in the OB, feedback was found to provide strong synaptic input to interneurons in the glomerular layer and to granule cells. Consistent with this connectivity pattern, activation of feedback projection triggered disynaptic inhibition in mitral/tufted cells. Intriguingly, optical stimulation of feedback projections from the anterior olfactory nucleus could also excite mitral cells with sufficient strength to trigger precisely timed spikes under some conditions. These methods can now be adapted to study the role of cortical feedback on odor coding and perception, for example by activating or inhibiting specific sources of feedback during odor-guided behaviors.

\section{Conclusions and outlook}

Careful quantitative measurements and manipulations of spatiotemporal activity patterns have refined current views of information processing at successive stages in the olfactory system. These studies also highlighted the power of optogenetic approaches to control neuronal activity patterns in space and time, and to explore systematic relationships between activity patterns and behavioral outputs. These approaches may now be used to address further important questions such as the roles of defined cell types in network function, the functions of different higher brain areas, and the role of top-down projections in the olfactory system.

\section{References}

Adrian ED (1950) The electrical activity of the mammalian olfactory bulb. Electroencephalogr Clin Neurophysiol 2:377-388. CrossRef Medline

Angelo K, Rancz EA, Pimentel D, Hundahl C, Hannibal J, Fleischmann A, Pichler B, Margrie TW (2012) A biophysical signature of network affiliation and sensory processing in mitral cells. Nature 488:375-378. CrossRef Medline

Arenkiel BR, Peca J, Davison IG, Feliciano C, Deisseroth K, Augustine GJ, Ehlers MD, Feng G (2007) In vivo light-induced activation of neural circuitry in transgenic mice expressing channelrhodopsin-2. Neuron 54: 205-218. CrossRef Medline

Arevian AC, Kapoor V, Urban NN (2008) Activity-dependent gating of lateral inhibition in the mouse olfactory bulb. Nat Neurosci 11:80-87. CrossRef Medline

Blumhagen F, Zhu P, Shum J, Schärer YP, Yaksi E, Deisseroth K, Friedrich RW (2011) Neuronal filtering of multiplexed odour representations. Nature 479:493-498. CrossRef Medline

Bozza T, McGann JP, Mombaerts P, Wachowiak M (2004) In vivo imaging of neuronal activity by targeted expression of a genetically encoded probe in the mouse. Neuron 42:9-21. CrossRef Medline
Buck LB (2000) The molecular architecture of odor and pheromone sensing in mammals. Cell 100:611-618. CrossRef Medline

Carey RM, Wachowiak M (2011) Effect of sniffing on the temporal structure of mitral/tufted cell output from the olfactory bulb. J Neurosci 31: 10615-10626. CrossRef Medline

Chapuis J, Wilson DA (2012) Bidirectional plasticity of cortical pattern recognition and behavioral sensory acuity. Nat Neurosci 15:155-161. CrossRef Medline

Chaput MA (1986) Respiratory-phase-related coding of olfactory information in the olfactory bulb of awake freely-breathing rabbits. Physiol Behav 36:319-324. CrossRef Medline

Chen TW, Lin BJ, Schild D (2009) Odor coding by modules of coherent mitral/tufted cells in the vertebrate olfactory bulb. Proc Natl Acad Sci U S A 106:2401-2406. CrossRef Medline

Cleland TA, Linster C (2012) On-center/inhibitory-surround decorrelation via intraglomerular inhibition in the olfactory bulb glomerular layer. Front Integr Neurosci 6:5. CrossRef Medline

Cohen JY, Haesler S, Vong L, Lowell BB, Uchida N (2012) Neuron-typespecific signals for reward and punishment in the ventral tegmental area. Nature 482:85-88. CrossRef Medline

Cury KM, Uchida N (2010) Robust odor coding via inhalation-coupled transient activity in the mammalian olfactory bulb. Neuron 68:570-585. CrossRef Medline

Davison IG, Ehlers MD (2011) Neural circuit mechanisms for pattern detection and feature combination in olfactory cortex. Neuron 70:82-94. CrossRef Medline

Dhawale AK, Hagiwara A, Bhalla US, Murthy VN, Albeanu DF (2010) Nonredundant odor coding by sister mitral cells revealed by light addressable glomeruli in the mouse. Nat Neurosci 13:1404-1412. CrossRef Medline

Doucette W, Restrepo D (2008) Profound context-dependent plasticity of mitral cell responses in olfactory bulb. PLoS Biol 6:e258. CrossRef Medline

Fantana AL, Soucy ER, Meister M (2008) Rat olfactory bulb mitral cells receive sparse glomerular inputs. Neuron 59:802-814. CrossRef Medline

Franks KM, Russo MJ, Sosulski DL, Mulligan AA, Siegelbaum SA, Axel R (2011) Recurrent circuitry dynamically shapes the activation of piriform cortex. Neuron 72:49-56. CrossRef Medline

Friedrich RW, Korsching SI (1997) Combinatorial and chemotopic odorant coding in the zebrafish olfactory bulb visualized by optical imaging. Neuron 18:737-752. CrossRef Medline

Friedrich RW, Laurent G (2001) Dynamic optimization of odor representations in the olfactory bulb by slow temporal patterning of mitral cell activity. Science 291:889-894. CrossRef Medline

Friedrich RW, Habermann CJ, Laurent G (2004) Multiplexing using synchrony in the zebrafish olfactory bulb. Nat Neurosci 7:862-871. CrossRef Medline

Gao Y, Strowbridge BW (2009) Long-term plasticity of excitatory inputs to granule cells in the rat olfactory bulb. Nat Neurosci 12:731-733. CrossRef Medline

Ghosh S, Larson SD, Hefzi H, Marnoy Z, Cutforth T, Dokka K, Baldwin KK (2011) Sensory maps in the olfactory cortex defined by long-range viral tracing of single neurons. Nature 472:217-220. CrossRef Medline

Gire DH, Schoppa NE (2009) Control of on/off glomerular signaling by a local GABAergic microcircuit in the olfactory bulb. J Neurosci 29:1345413464. CrossRef Medline

Gschwend O, Beroud J, Carleton A (2012) Encoding odorant identity by spiking packets of rate-invariant neurons in awake mice. PLoS One 7:e30155. CrossRef Medline

Haberly LB (2001) Parallel-distributed processing in olfactory cortex: new insights from morphological and physiological analysis of neuronal circuitry. Chem Senses 26:551-576. CrossRef Medline

Hagiwara A, Pal SK, Sato TF, Wienisch M, Murthy VN (2012) Optophysiological analysis of associational circuits in the olfactory cortex. Front Neural Circuits 6:18. CrossRef Medline

Hayar A, Karnup S, Shipley MT, Ennis M (2004) Olfactory bulb glomeruli: external tufted cells intrinsically burst at theta frequency and are entrained by patterned olfactory input. J Neurosci 24:1190-1199. CrossRef Medline

Igarashi KM, Ieki N, An M, Yamaguchi Y, Nagayama S, Kobayakawa K, Kobayakawa R, Tanifuji M, Sakano H, Chen WR, Mori K (2012) Parallel mitral and tufted cell pathways route distinct odor information to differ- 
ent targets in the olfactory cortex. J Neurosci 32:7970-7985. CrossRef Medline

Johnson BA, Leon M (2000) Modular representations of odorants in the glomerular layer of the rat olfactory bulb and the effects of stimulus concentration. J Comp Neurol 422:496-509. CrossRef Medline

Johnson DM, Illig KR, Behan M, Haberly LB (2000) New features of connectivity in piriform cortex visualized by intracellular injection of pyramidal cells suggest that "primary" olfactory cortex functions like "association" cortex in other sensory systems. J Neurosci 20:6974-6982. Medline

Kay LM, Laurent G (1999) Odor- and context-dependent modulation of mitral cell activity in behaving rats. Nat Neurosci 2:1003-1009. CrossRef Medline

Kazama H, Wilson RI (2009) Origins of correlated activity in an olfactory circuit. Nat Neurosci 12:1136-1144. CrossRef Medline

Kim DH, Phillips ME, Chang AY, Patel HK, Nguyen KT, Willhite DC (2011) Lateral connectivity in the olfactory bulb is sparse and segregated. Front Neural Circuits 5:5. CrossRef Medline

Kim DH, Chang AY, McTavish TS, Patel HK, Willhite DC (2012) Centersurround vs. distance-independent lateral connectivity in the olfactory bulb. Front Neural Circuits 6:34. CrossRef Medline

Knudsen EI (2007) Fundamental components of attention. Annu Rev Neurosci 30:57-78. CrossRef Medline

Koulakov AA, Rinberg D (2011) Sparse incomplete representations: a potential role of olfactory granule cells. Neuron 72:124-136. CrossRef Medline

Koulakov A, Gelperin A, Rinberg D (2007) Olfactory coding with all-ornothing glomeruli. J Neurophysiol 98:3134-3142. CrossRef Medline

Laurent G (2002) Olfactory network dynamics and the coding of multidimensional signals. Nat Rev Neurosci 3:884-895. CrossRef Medline

Leveteau J, MacLeod P (1966) Olfactory discrimination in the rabbit olfactory glomerulus. Science 153:175-176. CrossRef Medline

Lima SQ, Hromádka T, Znamenskiy P, Zador AM (2009) PINP: a new method of tagging neuronal populations for identification during in vivo electrophysiological recording. PLoS One 4:e6099. CrossRef Medline

Luna VM, Schoppa NE (2008) GABAergic circuits control input-spike coupling in the piriform cortex. J Neurosci 28:8851-8859. CrossRef Medline

Ma L, Qiu Q, Gradwohl S, Scott A, Yu EQ, Alexander R, Wiegraebe W, Yu CR (2012) Distributed representation of chemical features and tunotopic organization of glomeruli in the mouse olfactory bulb. Proc Natl Acad Sci U S A 109:5481-5486. CrossRef Medline

Matsutani S, Yamamoto N (2008) Centrifugal innervation of the mammalian olfactory bulb. Anat Sci Int 83:218-227. CrossRef Medline

Meister M, Bonhoeffer T (2001) Tuning and topography in an odor map on the rat olfactory bulb. J Neurosci 21:1351-1360. Medline

Miura K, Mainen ZF, Uchida N (2012) Odor representations in olfactory cortex: distributed rate coding and decorrelated population activity. Neuron 74:1087-1098. CrossRef Medline

Miyamichi K, Amat F, Moussavi F, Wang C, Wickersham I, Wall NR, Taniguchi H, Tasic B, Huang ZJ, He Z, Callaway EM, Horowitz MA, Luo L (2011) Cortical representations of olfactory input by trans-synaptic tracing. Nature 472:191-196. CrossRef Medline

Mori K, Takahashi YK, Igarashi KM, Yamaguchi M (2006) Maps of odorant molecular features in the mammalian olfactory bulb. Physiol Rev 86:409433. CrossRef Medline

Murlis J, Elkinton JS, Carde RT (1992) Odor plumes and how insects use them. Annu Rev Entomol 37:505-532. CrossRef

Murthy VN (2011) Olfactory maps in the brain. Annu Rev Neurosci 34: 233-258. CrossRef Medline

Nagayama S, Enerva A, Fletcher ML, Masurkar AV, Igarashi KM, Mori K, Chen WR (2010) Differential axonal projection of mitral and tufted cells in the mouse main olfactory system. Front Neural Circuits 4:120. CrossRef Medline

Niessing J, Friedrich RW (2010) Olfactory pattern classification by discrete neuronal network states. Nature 465:47-52. CrossRef Medline

Olsen SR, Bhandawat V, Wilson RI (2010) Divisive normalization in olfactory population codes. Neuron 66:287-299. CrossRef Medline

Padmanabhan K, Urban NN (2010) Intrinsic biophysical diversity decorrelates neuronal firing while increasing information content. Nat Neurosci 13:1276-1282. CrossRef Medline

Perez-Orive J, Mazor O, Turner GC, Cassenaer S, Wilson RI, Laurent G
(2002) Oscillations and sparsening of odor representations in the mushroom body. Science 297:359-365. CrossRef Medline

Petreanu L, Huber D, Sobczyk A, Svoboda K (2007) Channelrhodopsin-2assisted circuit mapping of long-range callosal projections. Nat Neurosci 10:663-668. CrossRef Medline

Poo C, Isaacson JS (2009) Odor representations in olfactory cortex: "sparse" coding, global inhibition, and oscillations. Neuron 62:850-861. CrossRef Medline

Restrepo D, Doucette W, Whitesell JD, McTavish TS, Salcedo E (2009) From the top down: flexible reading of a fragmented odor map. Trends Neurosci 32:525-531. CrossRef Medline

Rinberg D, Koulakov A, Gelperin A (2006) Sparse odor coding in awake behaving mice. J Neurosci 26:8857-8865. CrossRef Medline

Shao Z, Puche AC, Liu S, Shipley MT (2012) Intraglomerular inhibition shapes the strength and temporal structure of glomerular output. J Neurophysiol 108:782-793. CrossRef Medline

Shepherd GM, Chen WR, Greer CA (2004) Olfactory bulb. In: The synaptic organization of the brain (Shepherd GM, ed), pp 165-216. Oxford: Oxford UP.

Shusterman R, Smear MC, Koulakov AA, Rinberg D (2011) Precise olfactory responses tile the sniff cycle. Nat Neurosci 14:1039-1044. CrossRef Medline

Smear M, Shusterman R, O’Connor R, Bozza T, Rinberg D (2011) Perception of sniff phase in mouse olfaction. Nature 479:397-400. CrossRef Medline

Sosulski DL, Bloom ML, Cutforth T, Axel R, Datta SR (2011) Distinct representations of olfactory information in different cortical centres. Nature 472:213-216. CrossRef Medline

Soucy ER, Albeanu DF, Fantana AL, Murthy VN, Meister M (2009) Precision and diversity in an odor map on the olfactory bulb. Nat Neurosci 12:210-220. CrossRef Medline

Spors H, Grinvald A (2002) Spatio-temporal dynamics of odor representations in the Mammalian olfactory bulb. Neuron 34:301-315. CrossRef Medline

Spors H, Wachowiak M, Cohen LB, Friedrich RW (2006) Temporal dynamics and latency patterns of receptor neuron input to the olfactory bulb. J Neurosci 26:1247-1259. CrossRef Medline

Stettler DD, Axel R (2009) Representations of odor in the piriform cortex. Neuron 63:854-864. CrossRef Medline

Stokes CC, Isaacson JS (2010) From dendrite to soma: dynamic routing of inhibition by complementary interneuron microcircuits in olfactory cortex. Neuron 67:452-465. CrossRef Medline

Strotmann J, Conzelmann S, Beck A, Feinstein P, Breer H, Mombaerts P (2000) Local permutations in the glomerular array of the mouse olfactory bulb. J Neurosci 20:6927-6938. Medline

Suzuki N, Bekkers JM (2010) Inhibitory neurons in the anterior piriform cortex of the mouse: classification using molecular markers. J Comp Neurol 518:1670-1687. CrossRef Medline

Uchida N, Takahashi YK, Tanifuji M, Mori K (2000) Odor maps in the mammalian olfactory bulb: domain organization and odorant structural features. Nat Neurosci 3:1035-1043. CrossRef Medline

Wachowiak M (2011) All in a sniff: olfaction as a model for active sensing. Neuron 71:962-973. CrossRef Medline

Wachowiak M, Shipley MT (2006) Coding and synaptic processing of sensory information in the glomerular layer of the olfactory bulb. Seminars in cell and developmental biology 17:411-423. CrossRef Medline

Wiechert MT, Judkewitz B, Riecke H, Friedrich RW (2010) Mechanisms of pattern decorrelation by recurrent neuronal circuits. Nat Neurosci 13: 1003-1010. CrossRef Medline

Wilson DA, Sullivan RM (2011) Cortical processing of odor objects. Neuron 72:506-519. CrossRef Medline

Yaksi E, von Saint Paul F, Niessing J, Bundschuh ST, Friedrich RW (2009) Transformation of odor representations in target areas of the olfactory bulb. Nat Neurosci 12:474-482. CrossRef Medline

Yizhar O, Fenno LE, Davidson TJ, Mogri M, Deisseroth K (2011) Optogenetics in neural systems. Neuron 71:9-34. CrossRef Medline

Yokoi M, Mori K, Nakanishi S (1995) Refinement of odor molecule tuning by dendrodendritic synaptic inhibition in the olfactory bulb. Proc Natl Acad Sci U S A 92:3371-3375. CrossRef Medline

Zhu P, Fajardo O, Shum J, Zhang Schärer YP, Friedrich RW (2012) Highresolution optical control of neuronal activity patterns in space and time 
using a digital micromirror device in zebrafish. Nat Protoc 7:1410-1425.

CrossRef Medline 